\title{
Effective budgeting as a priority of the company>s development
}

\author{
S.B. Kashkimbayev ${ }^{1}$, A.N. Zhakupov ${ }^{2}$ \\ ${ }^{1}$ University of International Business «UIB», ${ }^{2}$ Auditors of the Republic of Kazakhstan
}

\begin{abstract}
In the modern world, in the conditions of economic instability and fierce competition, companies need to have effective tools that can provide an opportunity to study the current financial condition, compare cash inflows and outflows, approve the right decisions that contribute to the subsequent formation and development of the enterprise, as well as optimize management costs. In a company, such an important tool for financial planning, as well as control, is budgeting.

This article discusses the tasks, goals, methods, disadvantages and advantages of budgeting, illustrates the full continuous cycle of budget management and the stages of development of the concept of budgeting. In addition to the theoretical aspects, the article considers the empirical and methodological aspects. The purpose of this article is to generalize the theoretical provisions and develop the organizational and methodological aspects of the application of budgeting and the impact of effective budgeting on the development of the overall company. The article uses complex and systematic approaches to the processes and phenomena under study, which is achieved through the methods of analysis and synthesis, review and collection of information, statistical analysis, scientific abstraction and visualization.

In the conclusion of the article, the conclusions are made, that a properly formed concept of budgeting, improvement of methods and elements of the budget process will make it possible to manage the capital, as well as a single commercial, and the company as a whole, establishing the sequence of business types, terms and trends of restructuring. This will allow the owners of companies to adapt their business in time to all possible changes in market conditions.

Key words: budgeting, budget system, financial planning, budgeting stages, budgeting methods, budgeting objectives
\end{abstract}

\section{Тиімді бюджеттеу компания дамуының басымдығы ретінде}

\section{Түйін}

Қазіргі әлемде, экономикалық тұрақсыздық пен қатаң бәсекелестік жағдайында компаниялар қолданыстағы қаржылық жағдайды зерттеуге, ақша ағындары мен ағымдарын салыстыруға, кәсіпорынның кейінгі қалыптасуы мен дамуына ықпал ететін дұрыс ережелерді бекітуге, сондай-ақ басқару шығындарын оңтайландыруға мүмкіндік беретін тиімді құралдарға ие болуы керек. Компанияда қаржылық жоспарлаудың, сондай - ақ бақылаудың маңызды құралы-бұл бюджеттеу.

Бұл мақалада бюджеттеудің міндеттері, мақсаттары, әдістері, кемшіліктері мен артықшылықтары қарастырылады, бюджетті басқарудың толық тұрақты циклі және бюджеттеу тұжырымдамасының даму кезеңдері суреттелген. Теориялық тұрғыдан басқа, мақалада эмпирикалық және әдіснамалық аспектілер қарастырылған. Бұл мақаланың мақсаты-теориялық ережелерді жалпылау және бюджеттеуді қолданудың ұйымдастырушылық және әдістемелік аспектілерін дамыту және тиімді бюджеттеудің жалпы компанияның дамуына әсері. Мақалада зерттелетін процестер мен құбылыстарға кешенді және жүйелі тәсілдер қолданылады, оған әдістер арқылы қол жеткізіледі: талдау және синтездеу, ақпаратты шолу және жинау, статистикалық талдау, ғылыми абстракция және визуализация.

Мақаланың тұжырымында дұрыс құрылған бюджеттеу тұжырымдамасы, бюджеттік процестің әдістері мен элементтерін жетілдіру капиталды, сонымен қатар жеке коммерцияны да, тұтастай алғанда компанияны да басқаруға, бизнес түрлерінің дәйектілігін, мерзімдері мен қайта құрылымдау тенденцияларын белгілеуге мүмкіндік береді деген қорытынды жасалды. Бұл компания иелеріне өз бизнесін нарық жағдайындағы түрлі өзгерістерге уақытында бейімдеуге мүмкіндік береді.

$T_{Y}$ йін сөздер: бюджеттеу, бюджеттік жүйе, қаржылық жоспарлау, бюджеттеу кезеңдері, бюджеттеу әдістері, бюджеттеу міндеттері

\section{Эффективное бюджетирование как приоритет развития компании}

\section{Аннотация}

В современном мире в условиях экономической нестабильности и жесткой конкуренции компаниям необходимо обладать эффективным инструментарием, способным предоставить возможность изучить действующее финансовое состояние, сравнить денежные притоки и оттоки, утвердить правильные постановления, содействующие последующему формированию и развитию предприятия, а также оптимизировать управленческие расходы. В компании таким важным инструментом финансового планирования, а также контроля является бюджетирование.

В данной статье рассматриваются задачи, цели, методы, недостатки и преимущества бюджетирования, проиллюстрирован полный постоянный цикл бюджетного управления и этапы развития концепции бюджетирования. Помимо теоретических, в статье рассмотрены эмпирические и методологические аспекты. Целью данной статьи является обобщение теоретических положений и развитие организационнометодических аспектов применения бюджетирования и влияния эффективного бюджетирования на развитие 
компании. В статье применены комплексный и системный подходы к исследуемым процессам и явлениям, что достигнуто посредством методов: анализа и синтеза, обзора и сбора информации, научной абстракции и визуализации.

В результате проведенного исследования авторы пришли к выводу, что правильно сформированная концепция бюджетирования, усовершенствование способов и элементов бюджетного процесса даст возможность распоряжаться капиталом, равно как единичного предпринимателя, так и фирмы в целом, устанавливая последовательность разновидностей бизнеса, сроки и тенденции реструктуризации. Это позволит владельцам компаний вовремя адаптировать свой бизнес под всевозможные изменения условий рынка.

Ключевые слова: бюджетирование, бюджетная система, финансовое планирование, этапы бюджетирования, методы бюджетирования, задачи бюджетирования

\section{Introduction}

In the modern world, an important task of any enterprise is to increase its competitiveness. In these conditions, the survival, development and prosperity of any company is largely determined by the ability of its management to anticipate possible changes in a timely manner and make decisions that allow it to adapt to their consequences with maximum efficiency. There is an obvious need to establish a self-adjusting business system that can adequately and timely respond to environmental impacts in all areas.

Due to the constant complication of foreign economic conditions and the promotion of business, there is a need to constantly improve. To make the right management decisions, it is important to understand what is happening to the economy and the organization at the present time, what will happen in the short term, what material resources are available and what planned achievements the organization is striving for.

Therefore, it is very important for the managers of the enterprise to have the tools that can provide an opportunity to study the current financial condition, compare cash inflows and outflows, and approve the correct resolutions that contribute to the subsequent formation. In the company, such a mechanism of financial planning, as well as control, is called budgeting. [1]

Budgeting acts as a method of detailed accounting, optimization of management expenses. The origins of budgeting are laid in desk accounting, which are originated in Western Europe. General theoretical and methodological problems of the organization of financial planning and budgeting were studied by Western scientists V. Puehle, F. Gugli, I. T. Horngren, J. Foster. Scientists L. I. Gomberg, A. P. Rudanovsky, S. N. Chetverikov, N. D. Kondratiev, E. S. Stoyanova, M. I. Bukhalkov, made a significant contribution to the study of the budget in the commercial sector. The works of such Kazakhstani scientists as V. D. Li, D. V. Melnikov, Zh.M. Elubaeva, K. T. Taigashinov, B. S. Saparov and others are devoted to the development of financial activities of companies and their planning.

However, different scientists are investigating different budgeting systems (Table 1). Some consider the classical system of budgeting, others consider issues of traditional financial planning, and others consider process-oriented budgeting. Consequently, the role of budgeting in management is a subject for discussion not only among financiers and managers of companies, but also among representatives of science.

Table 1. Content of the definition of budgeting

\begin{tabular}{|l|l|}
\hline \multicolumn{1}{|c|}{ Author } & \multicolumn{1}{c|}{ Definition of budgeting } \\
\hline I. T. Horngren, J. Foster & $\begin{array}{l}\text { Believe that the budget can be identified with the category «plan», which acts as a quan- } \\
\text { titative representation of the plan. [2, p. 375] }\end{array}$ \\
\hline E. S. Stoyanova & $\begin{array}{l}\text { Identifies the concept of «budget» as a quantitative representation of the plan, which al- } \\
\text { lows you to show the income and expenses that have arisen for a specific period. In addi- } \\
\text { tion, the budget is the capital necessary for the implementation of target plans. [3, p. 144] }\end{array}$ \\
\hline I. A. Blank & $\begin{array}{l}\text { Budget-an operational financial plan drawn up for a short-term time period (less than 1 } \\
\text { year). In it, you could see the costs, financial receipts, characteristic of a particular eco- } \\
\text { nomic activity. [4, p. 98] }\end{array}$ \\
\hline
\end{tabular}

Analyzing the data in Table 1, the main thing in defining the concept of budget is that it is expressed in quantitative terms, which allows you to distinguish the budget from the broader concept of plan, since the latter may not have a quantitative expression. Companies need to regularly review their budgets and make relevant changes to them.
Budgeting is a single algorithm for setting projects and monitoring budget implementation in the realities of the chosen strategy. Thanks to this procedure, the relationship between financial planning and control is created, and the budget plan is effectively drawn up. 


\section{Methodology:}

The development of the company's budget is explained by an independent management function, which is considered a mandatory component of economic planning.

The selection of a specific method of budget development, its varieties and configurations take into account the distinctive features, goals and issues in the company's work.

The purpose of budgeting is to prepare and confirm financial goals aimed at forming a monetary mechanism, to study the restored work of common entities that contribute to the growth of the volume of production and sale of works or services.

Having achieved the above goals, you can solve such tasks as:

1) analyze the effectiveness of the use of current financial resources, as well as the search for unused reserves and the calculation of the company's cash reserve;

2) analyze the impact of aspects on the dynamics of the organization's finances;

3 ) identify the limits of uncertainty and risk, changing the economic characteristics, as well as aspects of the formation of the economic structure;

4) collect possible options for the movement of the company's financial indicators. For flexibility in calculations, a multivariate approach is needed, which will interact with both pessimistic and optimistic parameters;

5) calculate individual budgets using the principle of " bottom-up planning";

6) explain the organizational, economic and financial measures. [5]

A large number of managers of the organization take into account certain concepts when forming the budgeting system. There are many methods of implementing this procedure. In any of them, some direction of planning is reflected. namely:

There are many methods of budgeting,

1) The increment method. This is a classic method based on information about costs and income over the past period. This information is updated based on future price changes, possible changes in the volume of sales of goods. As a result, the increase in costs and revenues becomes a platform for setting budgets. The disadvantage of this method is that decisions made in the past that are not effective can become the basis for a new budget. The process of its formation is considered very time-consuming.

2) The zero-basis method. Any type of activity must first confirm the existence of the right of its future existence. To do this, you need to prove the future economic effectiveness of the allocated funds. This will allow the management to get the necessary information that will help to correctly prioritize further work.
3) The flexible budget method. To generate the report, data on the volume of sales of goods or services is used. When calculating it, variable and fixed costs are taken as planned, and volumes are taken as actual. This budget is drawn up in the form of a revenue and expenditure budget (RDB). The advantage of this method is the simplicity of accounting. The risk of using this approach is that it is difficult to focus full attention on doing business.

4) Line budget method (Line budget method). This is a large list of items. The analysis is performed for each individual position. This method is difficult to apply to large enterprises. In many cases, it is used by government agencies. It is difficult to monitor the implementation of the budget.

5) The stock method. It involves using different categories for cost planning. The main advantage of this method is the prostate. Minus there is no analysis of individual decisions, their potential impact on the company. [6]

The methodological order of budgeting in the company's financial planning system has its origins in the laws of systematics, composition, and the law of economic feasibility.

According to the systematics of the planning and analytical law, calculations take into account the relationship of a set of complex factors of the external and internal environment. The law of composition implies that the budget should be more detailed and planning and analytical calculations cannot include unnecessary data and should only consider the main points. The law of economic necessity (expediency) indicates that, based on the company's development plan, it is necessary to effectively use current finances, as well as attract reserves to raise the entire generation productivity of the enterprise.

As for the essence of budgeting, this process is continuous and systematic. This management technology must meet modern business requirements and contain mandatory stages of the management cycle, which in turn are intertwined with the main management functions: management setting, standardization, planning, regulation, motivation, supervision, etc. At the same time, the management cycle of the company must be constant and absolute. The mandatory stages of the management cycle (Figure 1) are:

1) reorganization of business processes;

2) preparation of the budget model;

3) approval of budgets;

4) execution and control;

5) deviation analysis;

6) analysis of critical success factors;

7) adjustment of strategic goals. 

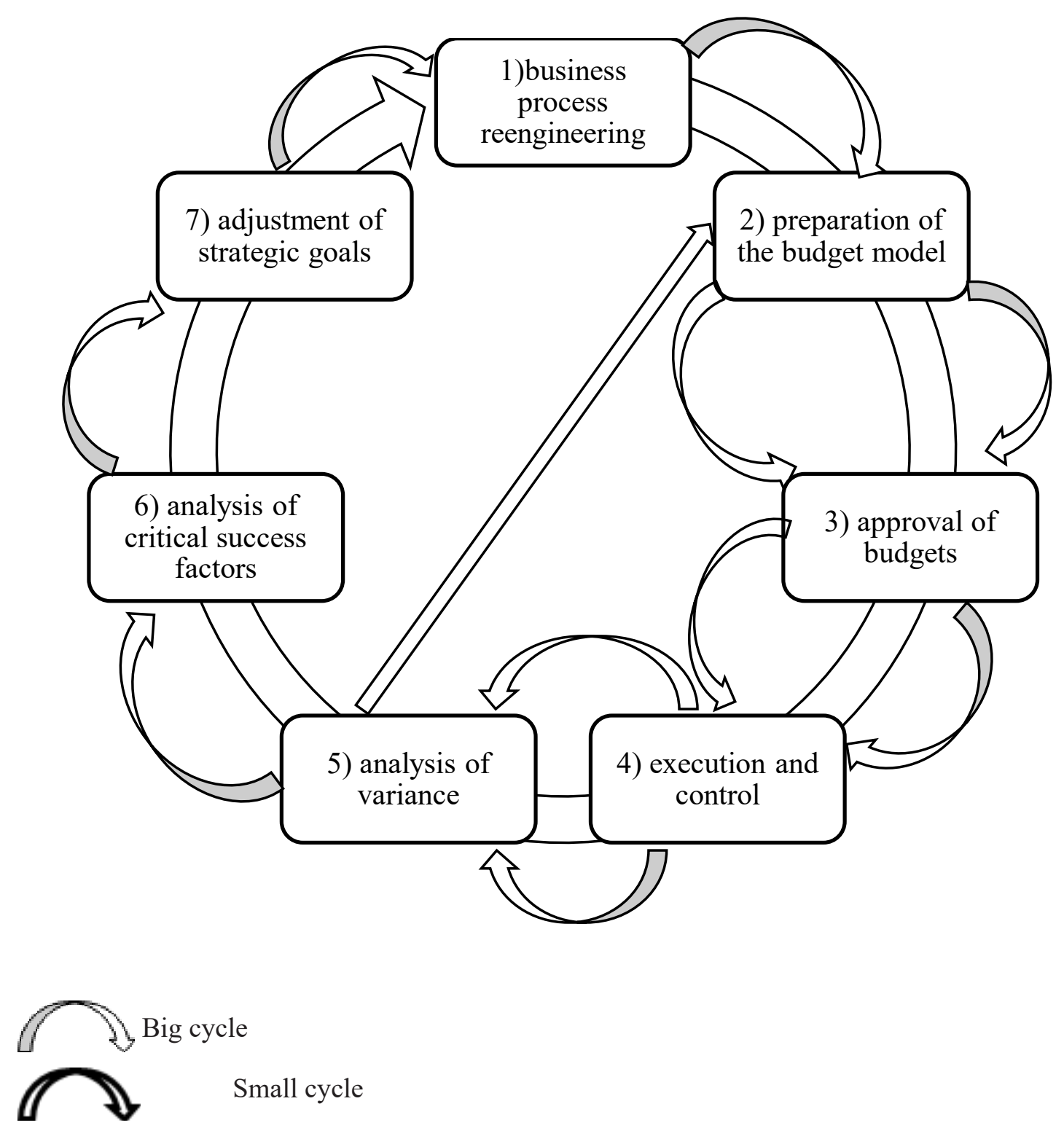

Picture 1. Complete continuous cycle of budget management stages in commercial organizations

According to the above circular algorithm (Picture 1 ), we divided the stages of budget management in commercial organizations into small and large continuous cycles. A small cycle indicates the stages of short - term, long-term planning, together forming a complete, continuous cycle of business budget management.

Business process reengineering is an important and fundamental link in technologies such as budgeting. This can be explained by the fact that when setting up this technology in the enterprise, you first need to adjust the existing business processes. Analyzing the performance indicators of the annual plan and the presence of impressive deviations from budgets in the business model of the commercial structure, top managers make adjustments to this stage, trying to increase production efficiency by this action.
1) «Business process reengineering» is a complete re-evaluation and redesign of existing processes in order to achieve sharp, abrupt upgrades of the main indicators (product cost, quality, service and production growth rates) of the company's activities.

2) «Preparation of the budget model» contains a «change» of the planned project in the management position. This model includes such data as profit and cost, cash flow, profit and loss statement, efficiency and margin of the provisions made, industrial project, revenue project, price strategy and cost, characteristics of the intensity and efficiency of production, etc.

The created business scheme is transferred to the adoption and establishment of the supreme management after the preliminary approval of the characteristics with the heads of the mediocre 
level. The approved business plan assumes the configuration of the permanent budget, which is not subject to correction during the planning stagethe budget for the year and/or during the specified period. This creates an active budget-monitoring for a month, the purpose of which is considered to be the result of the constant budget indicators. A dynamic budget, unlike a permanent budget, is likely to change during the planning phase. This is necessary so that the market entity represented by the middle management can quickly respond to the current favorable conditions or economic shocks.

«Execution and control (monitoring)» actions to achieve the planned indicators performed by performers and middle managers who, through monitoring, as well as evaluating the state and accounting for actual data of the operating activities of the enterprise.

"Variance analysis» is an analysis of the differences between actual and budget data. The differences can be both negative and positive, but, despite this, it is necessary to understand what caused this deviation, that is, its causes, its consequences, and what exactly it affected and to what extent. Then there are two scenarios, depending on the type of planning: in the short term, a «budget model» should be prepared, which takes into account the reasons for the actual deviations from the budget indicators, and the cycle begins anew; In the long term, the cycle goes through 2 more stages of budget management: «Analysis of critical success factors» and "Adjustment of strategic goals».

«Critical success Factors» (CSF) - analysis of the results that are needed to fulfill the organization's strategy and key performance indicators (KPIs) from the point of view of all company perspectives, including consumers, training and innovation, internal business, as well as traditional financial perspectives of monitoring the company's activities. These KPIs are the upper stage of performance monitoring for senior managers, but also, in turn, should be combined with more detailed operational parameters so that any failure to achieve the target KPIs can be monitored and corrected in a timely manner. [7]

The final stage of the budget management cycle is the «Adjustment of strategic goals». This stage is associated with the fact that if the company suddenly does not achieve the required level of budget indicators in the reporting period, then, consequently, the load on future time intervals will increase, and vice versa. The main factor influencing this stage is the ambitions of the top management or business owners (investors). At each stage, a «link» must be established»:

1) «top-down» - management plans are launched, as well as control is carried out (the ability to quickly maneuver in the event of externalinternal «shocks»);

2)» bottom - up « - budget execution, level of efficiency (production and team capabilities).

After setting the budgeting goals, the organization then distributes its economic resources. Accordingly, the main tasks of financial planning and budgeting include:

- support for current planning;

- confirmation of the organization's costs

- implementation of a framework for evaluating and monitoring the company's plans

- compliance with the requirements of laws, agreements and contracts.

Before drawing conclusions about the possible future financial development of the company, it is obvious that it is necessary to study its retrospective, identify trends of slowing and growth, that is, an assessment and analysis of the research subject. Then, on the basis of possible pessimistic, optimistic and optimal results of the development of the industry and the economic structure, an algorithm for taking control measures can be built. This algorithm is developed taking into account all the features of the functioning and organization of each subsystem. As a result, the main methodological positions and procedures for budgeting in the corporate structure can be formulated.

\section{Results and discussion}

Thus, it is necessary to distinguish the following main advantages of budgeting:

- monthly budget planning of individual business entities that are part of the corporate group, which provides more realistic indicators of the volume and structure of income and expenses than in the established forms of financial statements;

- it is possible for the structural divisions of the company, within the established budgets for the month, to independently decide on the transfer of funds between the items of expenditure of the organization (or the enterprise participating in the group);

- budget planning helps to save money for the corporation, which is especially important in the conditions of recovery from the economic crisis.

Therefore, the technology of budgeting is one of the main levers of financial management of companies. Budget management not only allows you to plan, but also to determine the causes of deviations, and therefore allows you to model the financial, natural and cost consequences of management decisions. The most common example is that meeting the revenue plan does not guarantee achieving the planned profit, and vice versa. 
Creating a budgeting system should help you evaluate the personal goals of the owner of the organization and the goals of the entire company.

It is customary to define a number of stages in the formation of the company's budget system:

1) Determining the capital structure of the company. A list of types of financial work is created, the management structure of the company is analyzed, and financial responsibility centers (CFOs) are formed.

2) Establishing a budgeting scheme. Elected variations and forms a key operational, spare budget, due to the procedure of different budgets in order CFA, the company installed the factors according to the integration of budgets.

3) Designation of the formats of the main budgets. The basic register of items of profit and expenses, cash receipts, capital withdrawals, assets and liabilities are chosen.

When developing the main budget formats, you need to meet these requirements:

- according to the structure, budgets are required to fully meet the international standards that are used in the financial accounting system;

- in terms of composition, budgets should be most fully consistent with Kazakhstan's accounting reporting forms;

- some items of expenditure may include types of costs whose share exceeds $1 \%$ in the volume of sales.

4) Definition of the budget regulations. At this stage, the budget preparation period is determined, the deadline for submitting budget reports to the $\mathrm{CFO}$, and the procedure for approving, changing, and integrating budgets.

During the adoption of the budget regulations, the budget period is important - the period during which the budget is valid, it can be adjusted, and the implementation is checked. Minimum budget period - a unit of measurement for the budget period (for example, a month).

5) Organization of the budget process. The list of participants in the budgeting procedure, the rules of their interaction are formed, tasks and functions are divided between the persons involved, and organizational and administrative documents are adopted.

6) Automation of financial calculations. The software is determined and adapted for the implementation of the development of financial plans of the organization in automatic mode. [8]

It is worth noting that the market economy itself is the most complex and represents an organized socio-economic system that requires special financial planning. At the same time, it is noted that the responsibility for possible negative consequences in the field of financing is fully assigned to the enterprise itself.
In our opinion, over the past decade, the financial planning process, which has already been formed into a single whole in many organizations, still needs to be adjusted. Therefore, to date, in this area, we can note such a list of shortcomings as:

- the beginning of the planning process begins with the creation, but not with the implementation of the finished product, in accordance with the "traditional" principle;

- the non-use of planning and economic evidence by various financial services at the capital planning stage, which in turn has a great impact on the investigation and correction of operations;

- false inhibition of the implementation of the financial planning movement, which adversely affects the application of planning characteristics in the adoption of specific and significant administrative decisions;

- the development of wholesale value depends on the unavailability of accounting for market conditions, which confirms the presence of the predominance of the accepted pricing mechanism;

- partial deficit of the distribution of costs into variable and stable ones. Do not use in practice the definition of "marginal profit", which occur in the course of financial planning, in certain organizations;

- lack of productivity assessment and calculation of the economic stability reserve;

- it is not feasible to perform a high-quality and productive review of the financial stability of the enterprise to regularly changing market circumstances.

- lack of effective regulatory framework for Kazakhstan's commercial sector. [9]

All this, in turn, has a negative impact on the company's activities, financial planning and budgeting. The root of most of the existing problems lies in the complete or partial absence of an organization's development strategy.

At the same time, to overcome the problems in the field of budgeting, it is important to formulate a unique strategy for the development of the company, which will reflect the financial aspect. This will help determine the desired goals and link the company's fiscal policy strategy to budget factors that have a direct impact on budgeting.

It is worth noting that the largest organizations have the right to implement effective budgeting. But at the same time, they have enough finances to hire professionals in their field who will be able to achieve the desired results in the field of finance.

Sometimes, in one way or another, in small firms, despite the significant need for financial planning, such a large amount of funds is not available. Small and medium-sized companies in order to provide their own economic work, 
significantly more often have the need to attract loan money, despite the fact that the external environment of such institutions is the most hostile and not always amenable to control. [10]

It follows from this that the significance of budgeting in the interests of an economic entity is as follows:

- the personification of the produced strategic goals in the configuration of accurate financial indicators;

- the financial ratios of the formation set in the production plan are supported by monetary resources;

- ensuring the potential to define the viability of a company's project in competitive circumstances;

- works as a tool for extracting financial assistance from external traders.

To implement optimal budgeting, modern companies create their own basic systems that affect the efficiency of the entire enterprise.

Therefore, enterprises need to comply with the following conditions in order to safely overcome the existing shortcomings of the budget system:

- systematically modernize the organizational structure in order to personalize management functions and responsibilities;

- execution of a technological order, appointment of responsible persons-this will allow you to automate some operations and simplify the process of budgeting;

- reduce the amount of data to specific standards for sharing with a wide range of business units;

- updating the accounting system, as it is the main supplier of the necessary data;

- correlate budgeting with the organizational and information structures of the company. [11, p. 92]

Therefore, a decrease in the financial efficiency and solvency of Kazakhstan companies, the need and rationality of introducing a modern technological management process, where in this case budgeting is a key aspect of the company's work. Thus, the main place of this kind of concept is to coordinate the general nuances of work and concentrate the efforts of comprehensive divisions, to achieve the planned results and ensure significant productivity of the enterprise.

\section{Conclusions}

Based on the above, we should be making these conclusions.

The desire to learn how to manage the financial flows of the company when working in an unstable external economic environment allows you to form the main task in the eyes of the head of the enterprise - to create effective budgeting, which would optimally affect the economic regulator of relations arising between different divisions of the company.

Thus, budgeting is a complex management procedure, which includes not only the responsibility of the company's employees, but also the adequate implementation of their functions. All this allows you to create an effective budgeting system that will be aimed at effective interaction. Budgeting allows you to manage the finances of both an individual business and the company as a whole, defining a set of business types, terms and directions of restructuring.

The successful implementation of suitable financial intentions guarantees a stable economic condition of the company, which is considered the makings of its effective functioning.

\section{References}

1. Bocharov V.V. Financial planning and budgeting: textbook.manual for bachelors of all forms of training in the specialty «Finance and credit» / V. V. Bocharov. - St. Petersburg: SPbGEU Publishing House, 2013

2. Stoyanova E.S. Financial management: theory and practice. 5th ed., reprint. and additional - M.: Perspektiva, 2013. - $656 \mathrm{p}$.

3. Blank I.A. Fundamentals of financial management. 2 volumes, 4th ed., - M.: Elga, Omega-L, 2012. $-1330 \mathrm{p}$.

4. Volkova O.N. Budgeting and financial control in commercial organizations. - M.: Finance and Statistics, 2005. - 272s.

5. Dobrovolsky E., Karabanov B., Borovkov P., Glukhov E., Breslav E. Budgeting: step by step. - St. Petersburg: «Peter», 2010. $-480 \mathrm{p}$.

6. Savostina O.V., Volkova M.A. Development of theoretical and methodological foundations of operational budgeting of industrial enterprises " production activities // Economics and Management: problems, solutions. 2018. Vol. 4. No. 3. pp. 106-110.

7. Gasanov G.I. Budgeting as a tool of financial planning at the enterprise. 2016. No. 11. pp. 1828-1833. URL: https://moluch.ru/archive/115/31265/ (accessed: 28.11.2019).

8. Voronova M.A. Stages of setting up a budgeting system for a cooperative organization. - 2015. - No. 7.3.

9. Brusov P.N., Filatova T.V. Financial management. Financial planning. (for bachelors). Training manual. Publishing house: Cambridge University press, 2016. Series the Bachelor. -232c.

10. Yarovov V. V., Zhukov N. In., Kurbatov, V. A. Modern approaches to the management of the budgeting process in a production plant // Bulletin of the Tula financial University. 2018. No. 1. P. 542-545.

11. Shcherba T.A., Kosykh V.V. Improving the budgeting system at production enterprises // Economic and management issues. 2016. No. 3-1. pp. 91-96.

12. Mayevskaya E.B. Strategic analysis and budgeting of cash flows of commercial organizations: 
Monograph / E. B. Mayevskaya. - M.: Infra-M, 2018. $-256 \mathrm{p}$.

13. Ladygin V.V. Budgeting and control at the enterprise. - M.: LENAND, 2020. - 530 p. / / [Internet resource] URL: http://urss.ru/253247

14. Samsonov N.F. Financial management. Enterprise Finance: textbook. Moscow: INFRA-M, 2017. 364 p.

15. Ilyin A.I. Planning at the enterprise: a textbook. 8th ed., ispr. i dop. Mn.: Novoe znanie, 2018. 700 p.

16. Gasanov, G. I. Budgeting as an instrument of financial planning at the enterprise. - 2019. - No. 11. - p. 1828-1833.
17. Bocharov V.V. Commercial budgeting: textbook. St. Petersburg: Peter, 2013. 368 p.

18. Ermilova M.I. Intra-corporate financial planning and budgeting. Textbook / M. I. Ermilova, E. O. Azizi, M. E. Kosov. - M.: Unity, 2018. - 336 p.

19. Andreev R.N. Economic essence and principles of budgeting / Modern trends in the development of science and technology. 2017. No. 3-11 (24). pp. 36-38.

20. Dudka E.S., Natarova E.V. Budgeting as a method of effective planning of enterprise activity. 2019. - No. 1. - pp. 351-357.

21. Stoyanova E.S. Financial management. 6th ed. Moscow: Perspektiva, 2018. 656 p.

\section{Information about the author}

Kashkimbayev Sabit Bogembayevich - corresponding author, University of International Business «UIB», Executive MBA UIB, Almaty, Abay Avenue, 8a Nazarbayev Street, Index: 050010, Phone: 87073174400 050010, 87073174400, e-mail: skbogem19@gmail.com, ORCID: 0000-0002-5282-2781, Researcher ID: AAC-89912021

Zhakupov Aidar Nurmukhanovich - Doctor of Economics, Auditor, member of the Chamber of Auditors of the Republic of Kazakhstan, ORCID: 0000-0003-3310-6875

\section{Авторлар туралы мәліметтер}

Кашкимбаев Сабит Богембаевич - хат-хабаршы авторы, Халықаралық бизнес университеті «UIB», мамандық Executive MBA «UIB», Алматы қ., Абай даңғылы, 8а, 050010, тел. 87073174400 050010, 87073174400, e-mail: skbogem19@gmail.com, ORCID: 0000-0002-5282-2781, Researcher ID: AAC-8991-2021

Жақупов Айдар Нұрмұханұлы - э. ғ. д., аудитор, ҚР аудиторлар палатасының мүшесі, ORCID: 00000003-3310-6875

Дата поступления: 02.02.2021.

Прошла рецензирование: 01.03.2021. Принято решение о публикации: 04.06.2021.

Received: 02.02.2021.

Reviewed: 01.03.2021. Accepted: 04.06.2021.

Қарастыруға қабылданды: 02.02.2021. Рецензиялауды өтті: 01.03.2021. Жариялауга қабылданды: 04.06.2021. 